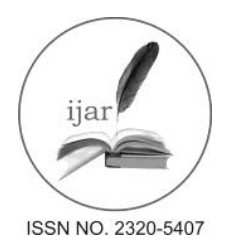

\author{
Journal homepage: http://www.journalijar.com

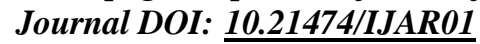
INTERNATIONAL JOURNAL
OF ADVANCED RESEARCH

RESEARCH ARTICLE

\title{
A NEW SPECIES OF CEROPEGIA (APOCYNACEAE: CEROPEGIEAE) FROM A MIDLAND LATERITIC HILL OF KERALA, INDIA.
}

\author{
Manudev K. M. ${ }^{1}$, Sharad S. Kambale ${ }^{2 *}$, C. Pramod $^{3}$ \& P.S. Prakash ${ }^{3}$. \\ 1. Department of Botany, St. Joseph's College, Devagiri, Kozhikode District, Kerala - 673 008, India. \\ 2. Department of Botany, MVP's Arts, Commerce and Science College, Tryambakeshwar, Nashik - 422 212, \\ India. \\ 3. Department of Botany, Govt. Brennen College, Thalassery, Kannur District, Kerala - 670 176, India.
}

\section{Manuscript Info \\ Manuscript History: \\ Received: March 2016 \\ Final Accepted: 22 April 2016 \\ Published Online: May 2016}

Key words:

India, southern Western Ghats,

Lateritic hills.

*Corresponding Author

Sharad S. Kambale.

\section{Abstract}

Ceropegia nampyana, a new species of Apocynaceae from the southern Western Ghats, is described and illustrated. The new species is morphologically allied to Ceropegia spiralis Hook.f. \& Thomson, but differs by having corolla lobes shorter than the tube, corolla tube glabrous within and hairy outer corona. The new taxon belongs to Ceropegia Ser. Attenuatae.

Copy Right,IJAR, 2016...All rights reserved.

\section{Introduction:-}

The genus Ceropegia L. includes more than 200 species distributed in the Old World ranging from South East Asia, India, Madagascar, Tropical Arabia, Canary Islands and Africa except the Mediterranean region, New Guinea and Northern Australia (Surveswaran et al. 2009). Karthikeyan et al. (2009) reported 56 species, 2 subspecies and 3 varieties from India which does not include a species published by Daniel and Umamaheswari (2001). Since then few more taxa have been published by different authors (Yadav \& Shendage 2010; Diwakar \& Singh 2011; Kambale et al. 2012; Rahangdale \& Rahangdale 2012) and the genus is now represented by 66 taxa (59 species, two subspecies and five varieties) in India. Western Ghats is the centre of diversity of the genus in India which harbors 46 taxa (Nair et al. 2014) of which 20 species and 2 varieties occur in Kerala (Nair et al. 2006). An interesting species of Ceropegia has been collected from the lateritic hill Pokkunnu, near Nanminda in Kozhikode district of Kerala. Following consultation of the relevant literature and a detailed study, the specimen was identified as a new species, which is described and illustrated here. This new taxon belongs to the series Attenuatae H.Huber under sect. Tiloris H.Huber.

Ceropegia nampyana Manudev, Kambale \& Pramod, sp. nov. Figs. 1A-H, 2C\&D:-

Ceropegia nampyana is close to C. spiralis Wight but differs by having corolla lobes shorter than the tube, corolla tube glabrous within, hairy outer corona as opposed to corolla lobes as long as corolla tube, bulbous based conical trichomes present within tube, glabrous outer corona in C. spiralis.

Types:- INDIA, Kerala, Kozhikode District, 25 km from Kozhikode city, Nanminda, Pokkunnu, 13.IX.2014, Manudev, Pramod \& Prakash 138969 (Holotype CALI!; Isotypes: DEV!, SUK!) 
Perennial erect herbs. Rootstock tuberous, tubers $1.5-2 \mathrm{~cm}$ across, globose-discoid; roots fibrous. Stem terete, pubescent, unbranched, up to $9-15 \mathrm{~cm}$ high, c. $3 \mathrm{~mm}$ across. Leaves simple, opposite, decussate, petiolate; petiole $4-6 \mathrm{~mm}$ long, channeled above, glabrous; lamina $4.5-10 \times 0.8-1 \mathrm{~cm}$, linear to elliptic-lanceolate, falcate, acute at apex and narrowed at base, glabrous, margins serrulate, strigose towards base. Inflorescence a solitary, extraaxillary flower, shortly pedunculate; peduncles $1.5-2 \mathrm{~mm}$ long, terete, glabrous; bract solitary, $1.5-2 \mathrm{~mm}$ long, linear, glabrous; pedicels $0.8-1 \mathrm{~cm}$ long, terete, glabrous. Calyx 5-partite, sepals $2.5-3.5 \mathrm{~mm}$ long, linearsubulate, glabrous. Corolla c. $3 \mathrm{~cm}$ long; tube c. $2 \mathrm{~cm}$ long, slightly curved, glabrous, dilated at base, narrow at middle, funnel shaped above, pale green with purple bands at base, deep purple otherwise, glabrous and deep purple within, dilated portion glabrous within; corolla lobes up to $1.3 \mathrm{~cm}$ long, shorter than the tube, twisted, acute, folded along the margin, connate at the tip, glandular trichomes present along margins; trichomes clavate, purple and translucent; unicellular conical purple trichomes present within at the base of corolla lobes. Corona biseriate; outer corona bowl-shaped, c. $1.2 \times 2.5 \mathrm{~mm}$, with 5 - bifid lobes; lobes c. $0.5 \mathrm{~mm}$, hairy along margin and within; inner corona erect, whitish-cream coloured, linear, c. $2.5 \mathrm{~mm}$ long, alternate with outer corona. Pollinia yellow, attached to brown pollen carriers by short caudicles, Pollinarium c. $0.35 \times 0.45 \mathrm{~mm}$, yellow. Follicles in pairs, $6-7 \times 0.3 \mathrm{~cm}$, glabrous, tapering towards apex, usually unequal. Seeds c. $5 \times 3 \mathrm{~mm}$, ovate-oblong, comose; coma c. $2 \mathrm{~cm}$ long, white, silky.

Distribution:- Hitherto known from the type locality.

Phenology:- Flowering and fruiting after monsoon; flowers and fruits were collected in October.

Etymology:- This species is named in honour of Professor Santhosh Nampy, Department of Botany, University of Calicut, Kerala, for his valuable contribution to the field of Angiosperm taxonomy, who guided the first author to the field of taxonomical research.

Conservation Status:- Ceropegia nampyana is so far known from the type locality only. About 30 individuals were located. According to IUCN criteria, the species falls under the category Data Deficient (DD) (IUCN 2001, 2010)

Notes:- Series Attenuatae H.Huber is endemic to peninsular India, particularly to the Western Ghats, which is one of the centres of diversity of Ceropegia (Malpure et al. 2006). They are characterized by linear or linear-lanceolate leaves, globose tubers, sessile or shortly pedunculate, uni- or few-flowered, bracteate cymes and corolla lobes that are connate at the apex. Presence of unicellular glandular trichomes and clavate translucent trichomes on corolla lobes are unusual in the Series Attenuatae, which is seen only in C. spiralis Wight and C. nampyana. Now, this series is represented by 13 species in India including the new taxon. Of these 13 species, Ceropegia anantii S.R.Yadav, Sardesai \& S.P.Gaikwad, C. anjanerica Malpure, M.Y.Kamble \& S.R.Yadav, C. attenuata Hook., $C$. concanensis Kambale, Chandore \& S.R.Yadav, C. jainii Ansari \& B.G.Kulk., C. mohanramii S.R.Yadav, M.N.Gavade \& Sardesai and C. nampyana Manudev, Kambale \& Pramod grows in lateritic plateaus or hillocks. The remaining species viz., $C$. bhatii S.R.Yadav \& Shendage, $C$. fimbriifera Bedd., $C$. mahabale $i$ Hemadri \& Ansari, $C$. pullaiahii Raja Kullayisw., Sandhyar. \& Karupp., C. noorjahaniae Ansari and C. spiralis Wight grows in dry deciduous forests or open scrub forests, along dry hill slopes among grasses and succulent Euphorbias. An updated taxonomic key to the species of Series Attenuatae in India is provided for the easy identification in the field.

Table 1. Comparison between Ceropegia nampyana and C. spiralis

\begin{tabular}{|l|l|l|}
\hline Character & Ceropegia nampyana & Ceropegia spiralis \\
\hline Corolla tube & Glabrous and deep purple within & $\begin{array}{l}\text { Bulbous based conical trichomes present } \\
\text { within the tube; deep pink within at lower } \\
\text { half and greenish at upper half }\end{array}$ \\
\hline Corolla lobes & $\begin{array}{l}\text { Shorter than corolla tube and } \\
\text { twisted }\end{array}$ & $\begin{array}{l}\text { As long as corolla tube and spirally } \\
\text { coiled }\end{array}$ \\
\hline Outer corona & Hairy along margin and within & Glabrous throughout \\
\hline
\end{tabular}

Ecology and Habitat:- Ceropegia nampyana was collected from a midland lateritic hill, Pokkunnu, situated $25 \mathrm{~km}$ away from the Kozhikode city. The species was found growing in the shallow soil pockets near laterite rocks, in association with Murdannia semiteres (Dalzell) Santapau, Ischaemum ciliare Retz., Gloriosa superba L., Cyanotis burmanniana Wight, Pogostemon quadrifolius (Benth.) F.Muell., Justicia japonica Thunb., Polycarpaea corymbosa (L.) Lam., Eriocaulon eurypeplon Körn., Crotalaria nana Burm.f., Canscora pauciflora Dalzell and species of Arundinella. 
The climatic conditions in different seasons together with edaphic factors account for the development of characteristic vegetation on the midland lateritic hills and plateaus of Northern Kerala. The great diversity shown by these habitats are influenced by different factors such as physical and chemical properties of the soil, microclimate and varied types of geographical terrains which form a number of micro ecosystems. As indicated by Barthlott and Porembski (2000), lateritic plateaus can be treated as model ecosystems similar to oceanic islands. In the last few years, a number of new taxa were described from the lateritic plateaus of Southern and Western Coast of India, especially from Northern Kerala, that include Nymphoides krishnakesara (Joseph \& Sivarajan 1990); Rotala malabarica (Pradeep et al. 1990); Justicia ekakusuma (Pradeep \& Sivarajan 1991); Lepidagathis keralensis (Madusoodhanan \& Singh 1992); Coelachne madayensis (Pramod et al. 2012); Lindernia madayiparensis (Ratheesh Narayanan et al. 2012); Parasopubia hofmannii (Pradeep \& Pramod 2013); Eriocaulon cheemenianum (Biju et al. 2012); Eriocaulon gopalakrishnanum (Rasmi \& Krishnakumar 2013); Canscorinella bhatiana (Subrahmanya Prasad \& Raveendran 2012, Shahina \& Nampy 2014); Eriocaulon kannurense (Sunil et al. 2012); Rotala khaleeliana (Sunil et al. 2013); Rotala tulunadensis (Subrahmanya Prasad et al. 2012); Rotala meenkulamensis (Subrahmanya Prasad \& Raveendran 2013a); Rotala kasaragodensis (Subrahmanya Prasad \& Raveendran 2013b) and Brachystelma vartakii (Kambale et al. 2014).

These lateritic plateaus have high conservation value owing to the presence of a number of endemic, rare and habitat specific species of plants and animals. The lack of awareness of this aspect is leading to various destructive activities, especially mining for laterite bricks and clay. One such activity at the type locality is a major threat to the new taxon.

Key to the species of Ceropegia Ser. Attenuatae H.Huber (Sect. Tiloris H.Huber)

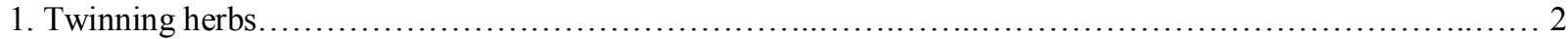

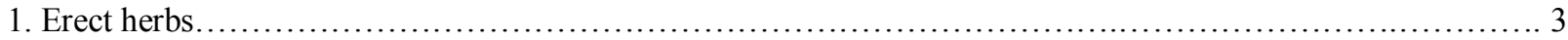

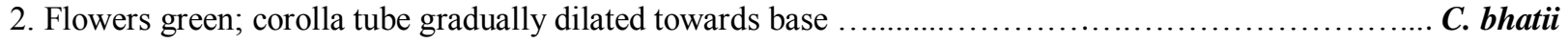

2. Flowers blotched with deep pink spots; corolla tube globose at base $\ldots \ldots \ldots \ldots \ldots \ldots \ldots \ldots \ldots \ldots \ldots \ldots$. pullaiahii

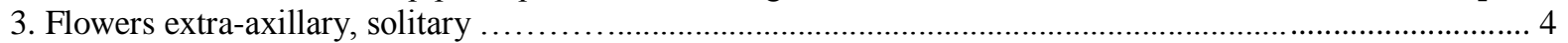

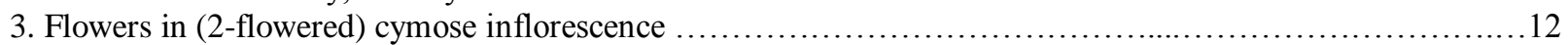

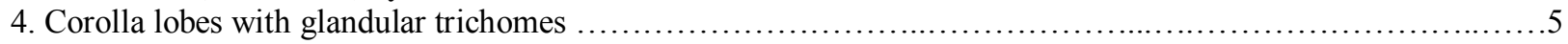

4. Corolla lobes not as above..................................................................... 6

5. Corolla lobes spirally coiled; tube with bulbous based trichomes within; outer corona glabrous

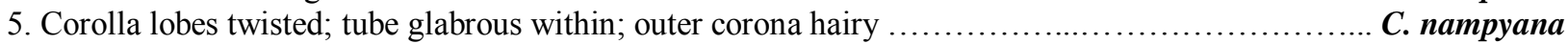

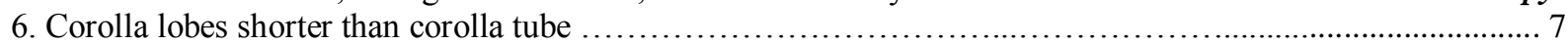

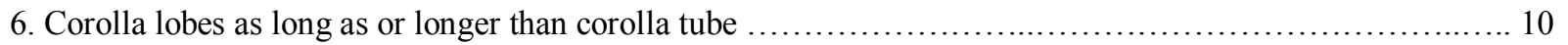

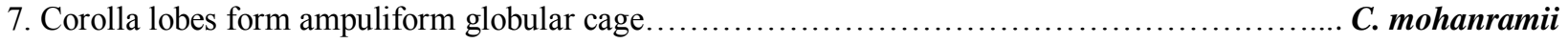

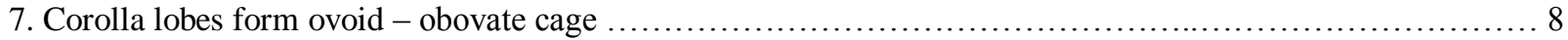

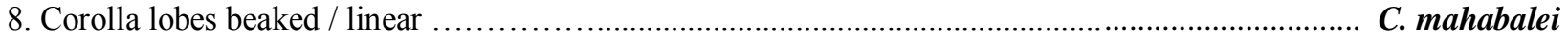

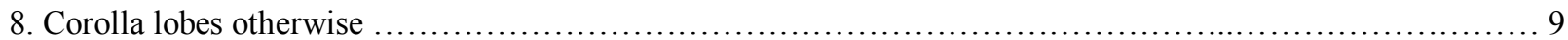

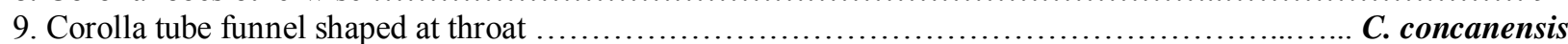

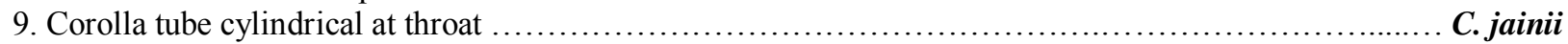

10. Corolla lobes with deep purple spot at either side at the base ................................... anantii

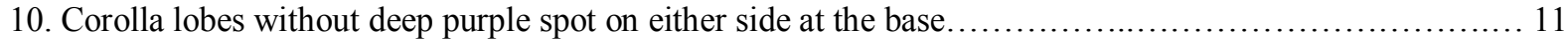

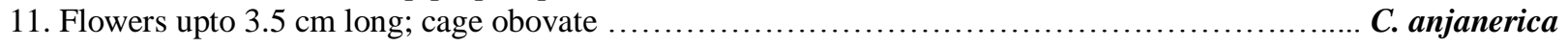

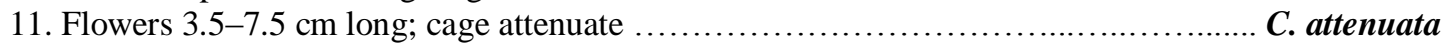

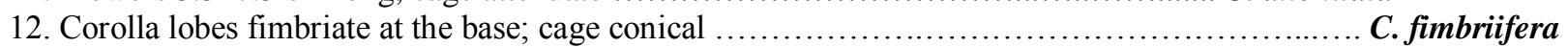

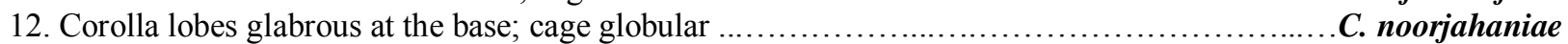



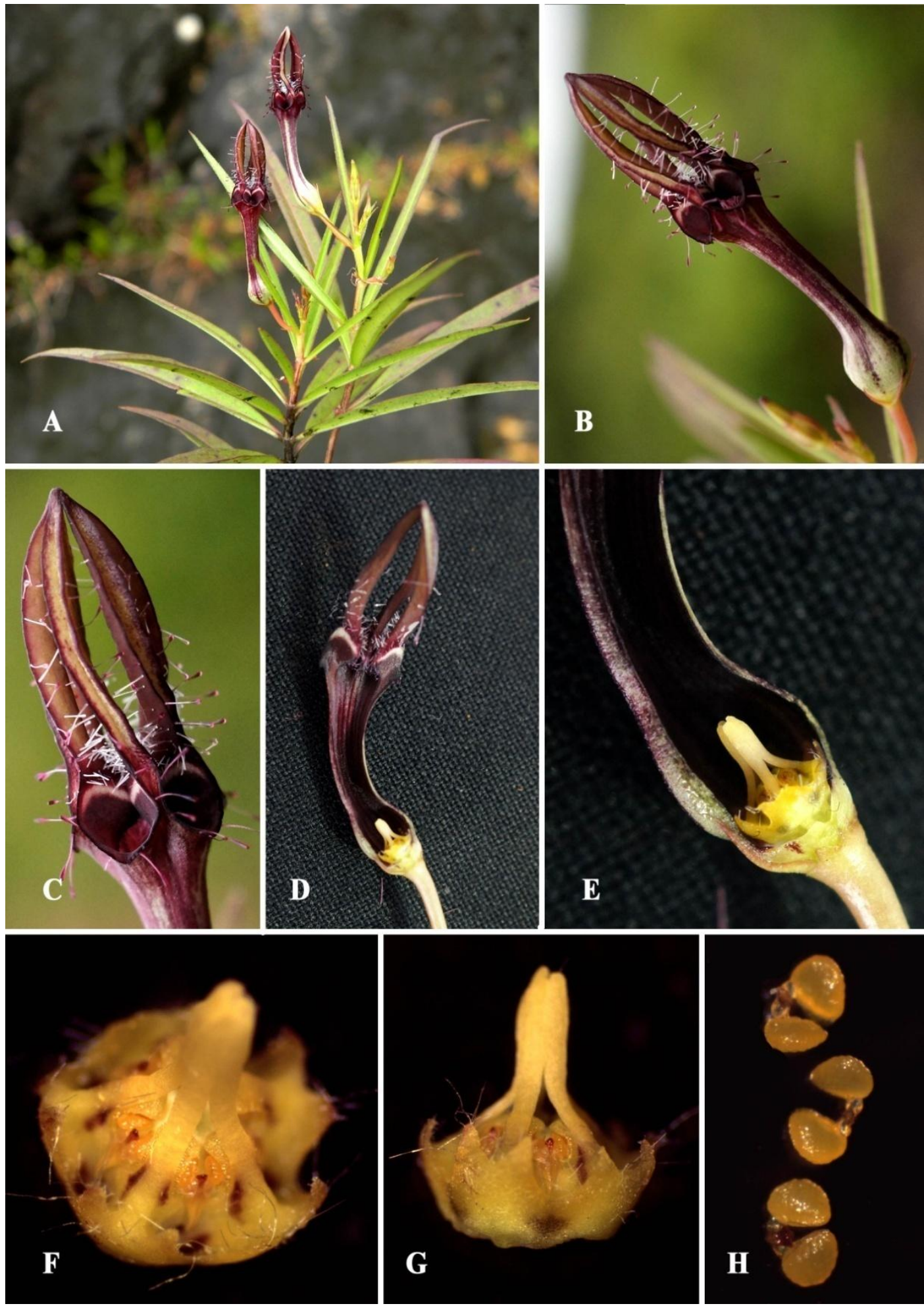

Fig. 1:- Ceropegia nampyana Manudev, Kambale \& Pramod: A. Habit; B. Flower; C. Twisted corolla lobes with glandular trichomes; D. Longitudinal section of flower; E. Longitudinal section of corolla tube; F \& G. Corona; H. Pollinia (All from Manudev, Pramod \& Prakash 138969). Photos: Manudev \& Pramod. 

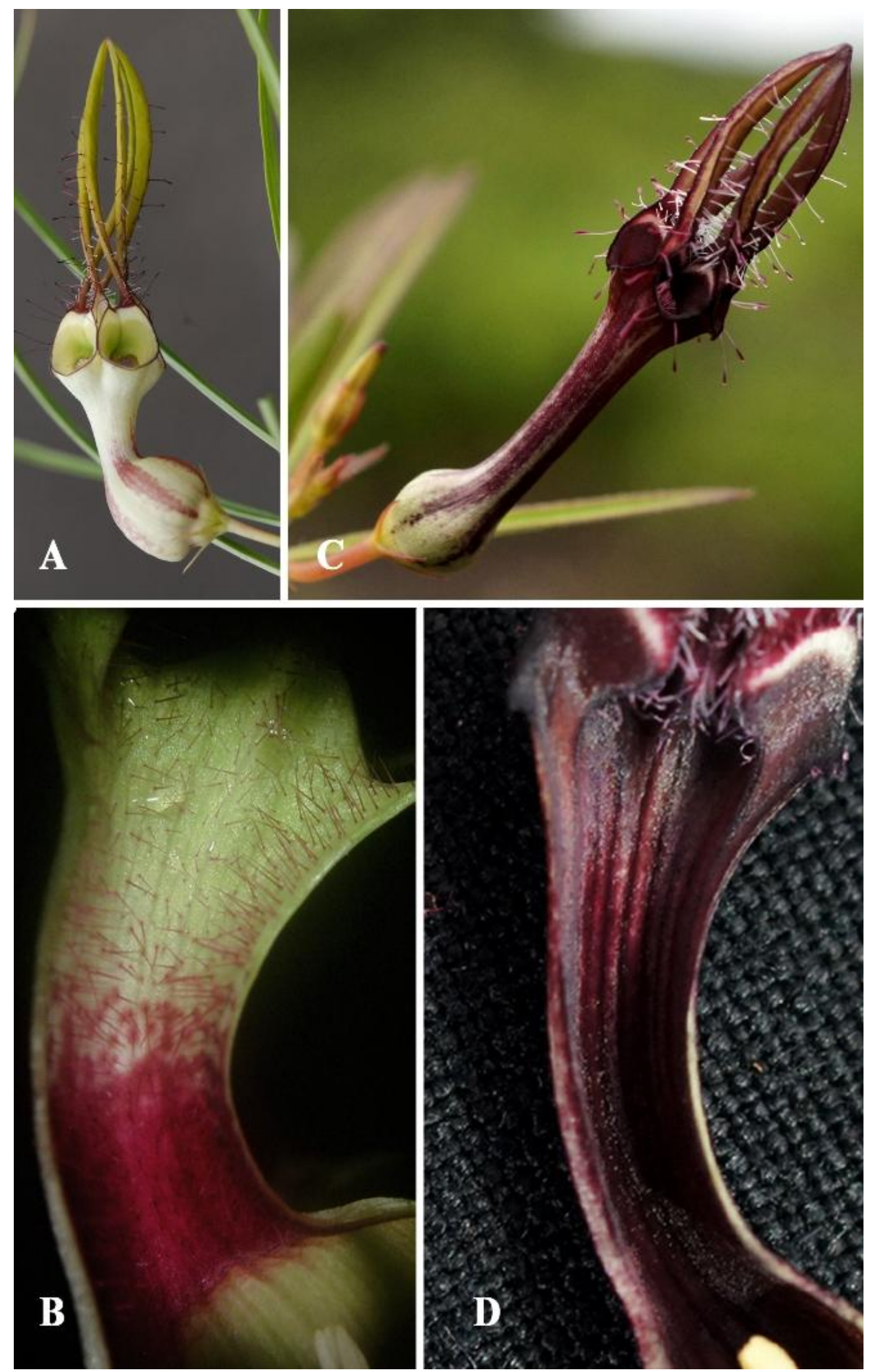

Fig. 2:- A \& B. Ceropegia spiralis: A. Flower; B. Longitudinal section of corolla tube. C. \& D. Ceropegia nampyana: C. Flower; D. Longitudinal section of corolla tube. Photos: Kambale \& Manudev. 


\section{Acknowledgements:-}

Authors are thankful to The Principal, St. Joseph's College, Devagiri, Kozhikode and Prof. M.K. Janarthanam, Department of Botany, University of Goa for Laboratory facilities; Mr. Nikhil Krishna for assistance in the field. MKM and SSK thank University Grants Commission (UGC) for financial assistance..

\section{References:-}

1. Barthlott, W. and S. Porembski, 2000. Why Study Inselbergs. In: Porembski S, Barthlott W (Eds.), Inselbergs: Biotic diversity of isolated outcrops in tropical and temperate regions. Ecological Studies, Vol. 146. SpringerVerlag, Berlin. pp. $1-6$.

2. Biju, P., Subrahmanya Prasad, K., Ajith Kumar, P., Augustine, J., Raveendran, K. and R. Ansari, 2012. Eriocaulon cheemenianum (Eriocaulaceae), a new species from Kerala, India. International Journal of Plant Animal and Environmental Science 2(4): 176 - 179.

3. Daniel, P. \& Umamaheswari, P. 2001. The Flora of the Gulf of Mannar, Southern India. Botanical Survey of India, Calcutta.

4. Diwakar, P. G. and R.K. Singh, 2011. A new variety of Ceropegia attenuata Hook. (Asclepiadaceae) from Mookambika Wild Life Sanctuary, Karnataka, India. Indian Journal of Forestry 34: 209 - 212.

5. Joseph, K. T. and V. V. Sivarajan, 1990. A new species of Nymphoides (Menyanthaceae) from India. Nordic Journal of Botany 10(3): $281-284$.

6. IUCN, 2001. IUCN Red List Categories and Criteria, Version 3.1. Prepared by IUCN Species Survival Commission. IUCN, Gland and Cambridge.

7. IUCN Standards and Petitions Subcommittee, 2010. Guidelines for Using the IUCN Red List Categories and Criteria, Version 8. Prepared by the Standards and Petitions Subcommittee in March 2010.

8. Kambale, S. S., Chandore, A. N. and S.R. Yadav, 2012. Ceropegia concanensis, a new species (Apocynaceae: Ceropegieae) from Western Ghats, India. Kew Bulletin 67: 843 - 848.

9. Kambale, S. S., Surveswaran, S. and S.R. Yadav 2014. Two new species of Brachystelma Sims (Apocynaceae: Asclepiadoideae - Ceropegieae) from the Western Ghats of India. Kew Bulletin doi 10.1007/S12225-014-94931.

10. Karthikeyan, S., Sanjappa, M. and S. Moorthy, 2009. Flowering plants of India. Vol. 1, Dicotyledons (Acanthaceae - Avicenniaceae), Botanical Survey of India, Calcutta. pp. 160 - 164.

11. Madhusoodanan, P. V. and N.P. Singh, 1992. A New Species of Lepidagathis (Acanthaceae) from South India. Kew Bulletin 47 (2): $301-303$.

12. Malpure, N. V., Kamble, M. Y. and S.R. Yadav, 2006. A new species of Ceropegia L. (Asclepiadaceae) from the Western Ghats of India with a note on Series Attenuatae H.Huber. Current Science 91: 1140-1142.

13. Nayar, T. S., Rasiya Beegam, A. and M. Sibi, 2014. Flowering plants of the Western Ghats, India. JNTBGRI, Thiruvananthapuram. p. 933.

14. Nayar, T. S., Rasiya Beegam, A., Mohanan, N. and G. Rajkumar, 2006. Flowering plants of Kerala- A Handbook. JNTBGRI, Thiruvananthapuram. p. 1069.

15. Pradeep, A. K. and C. Pramod, 2013. Parasopubia hofmannii Pradeep \& Pramod and Parasopubia hofmannii var. albiflora Pradeep \& Pramod (Orobanchaceae), Two New Taxa from India. Candollea 68(1): 115-122.

16. Pradeep, A. K. and V.V. Sivarajan, 1991. Justicia ekakusuma, A new species of Acanthaceae from Peninsular India. Rheedea 1: 40-43.

17. Pradeep, A. K., Joseph, K. T. and V.V. Sivarajan, 1990. Rotala malabarica, a new species of Lythraceae from India. Botanical Bulletin Academica Sinica 31: 59-61.

18. Pramod, C., Pradeep, A. K. and J.F. Veldkamp, 2012. Coelachne madayensis (Poaceae: Pooideae: Isachneae), a new species from Kerala, India. Gardens Bulletin 64(2): 289-292.

19. Rahangdale, S. S. and S.R. Rahangdale, 2012. Variety novae of Ceropegia mahabalei Hemadri \& Ansari (Apocynaceae: Asclepiadoideae). Indian Forester 138: 201-203.

20. Rashmi, K. and G. Krishnakumar, 2014. Eriocaulon gopalakrishnanum sp. nov. (Eriocaulaceae) from the Western Ghats, India. Nordic Journal of Botany 32: 146-149.

21. Ratheesh Narayanan, M. K., Sunil, C. N., Nandakumar, M. K., Sujana, K. A., Jayesh, P. J. and N. Anil Kumar, 2012. Lindernia madayiparense (Linderniaceae) - a new species from Kerala, India. International Journal of Plant Animal and Environmental Science 2(3): 60-62.

22. Shahina, P. M. and S. Nampy, 2014. A taxonomic revision of the genus Canscora in South India, and the erection of the new genus Canscorinella (Canscorinae, Gentianaceae) with two new combinations. Phytotaxa 164 (4): 201-225. 
23. Subrahmanya Prasad, K. and K. Raveendran, 2012. Canscora bhatiana (Gentianaceae), a new species from Kerala, India. International Journal of Plant Animal and Environmental Science 2(4): 197-201.

24. Subrahmanya Prasad, K. and K. Raveendran, 2013a. A new species of Rotala L. (Lythraceae) from Kerala, India. Taiwania 58(2): 104-107.

25. Subrahmanya Prasad, K. and K. Raveendran, 2013b. Rotala kasaragodensis (Lythraceae), a new species from Kerala, India. Edinburgh Journal of Botany 70 (3): 451-454.

26. Subrahmanya Prasad. K., Biju. P., Raveendran, K. and K.G. Bhat, 2012. Rotala tulunadensis sp. nov. (Lythraceae) from Kerala, India. Nordic Journal of Botany 30: 58-60.

27. Sunil, C. N., Ratheesh Narayanan, M. K., Nandakumar, M. K., Sujana, K. A., Jayesh, P. J. and N. Anil Kumar, 2012. Eriocaulon kannurense (Eriocaulaceae), a new species from Kerala, India. International Journal of Plant Animal and Environmental Science 3 (2): 116-120.

28. Sunil, C. N., Ratheesh Narayanan, M. K., Nandakumar, M. K., Abdul Jaleel, V. and N. Anil Kumar, 2013. Rotala khaleeliana sp. nov. (Lythraceae), a new species from lateritic hills of Kannur, Kerala, India. International Jouranal of Advanced Research 1(2): 14-16.

29. Surveswaran, S., Kamble, M. Y., Yadav, S. R. and M. Sun, 2009. Molecular phylogeny of Ceropegia (Asclepiadoideae, Apocynaceae) from Indian Western Ghats. Plant Systematics and Evolution 281: 51-63.

30. Yadav, S. R. and S. M. Shendage, 2010. Ceropegia bhatii, a new species of Apocynaceae: Ceropegieae from Karnataka, India. Kew Bulletin 65: 107-110. 